\title{
Special Issue: Towards Better BITs? - Making International Investment Law Responsive to Sustainable Development Objectives An Introduction
}

\author{
Andreas R. Ziegler \\ University of Lausanne, Lausanne, Switzerland \\ andreas.ziegler@unil.ch
}

The field of international investment law has caused a lot of controversy in recent years. In my view, this is first and foremost due to the higher visibility of bilateral investment treaties (BITs) or international investment agreements (IIAs), as they are alternatively called. This increased visibility is itself a result of the high number of investor-state disputes that have become known in recent years and the attempt to negotiate a multilateral agreement on investment (MAI) in the framework of the Organization for Economic Cooperation and Development (OECD) in the late 1990s. ${ }^{1}$

Although these multilateral investment negotiations at the OECD came to a standstill in 1998, the parallel increase of bilateral and regional trade negotiations (due to the difficulties in concluding the Doha Round of the World Trade Organization [WTO]) has opened the way for the inclusion of investment chapters in many (if not most) regional trade (and investment) agreements. While the attempted inclusion of investment in the WTO negotiations as one of the so-called Singapore Issues in 1996 failed, bilateral negotiations now normally include a discussion on whether to include investment liberalization and protection rules - and most often these negotiations lead to a respective chapter on investment rules in preferential trade and investment agreements. ${ }^{2}$

1 The United Nations Conference on Trade and Development (UNCTAD) regularly reports on the number of known BITs and related disputes in its annual reports see most recently its World Investment Report (United Nations 2014).

2 On the combination of trade and investment rules in this new type of treaty, see also the contributions in Rainer Hofmann, Stephan Schill and Christian Tams (eds.), Preferential Trade and Investment Agreements: From Recalibration to Reintegration (Nomos 2013). 
The controversy on international investment law is particularly related to the known disputes that result from the inclusion of investor-State dispute settlement (ISDS) provisions in these IIAs. While the mechanism as such - in particular granting private investors the right to request the establishment of an international arbitration tribunal against a sovereign State - has always caused controversy, the high number of resulting arbitral awards has highlighted for the first time the many challenges that the traditional rules contained in most BITs or IIAs present when States have increased needs for capital from foreign investors and at the same time have to safeguard various public interests in a quickly changing environment. Many of the investment disputes lead to awards that are (partly) in favor of the claimant and thus oblige the respondent State to pay damages to a private party. It seems that in many cases governments and other State entities have problems to fully envisage the consequences of their decisions and are incapable of respecting many of the guarantees - at least as interpreted by the respective arbitrators contained in IIAs.

The reaction to the increasing amount of damages to be paid as a result of these arbitral awards has been at least threefold:

A first reaction has been to argue that the conclusion of BITs as such is detrimental to a State's sovereignty and its right to regulate in the public interest. As a result some States have terminated certain agreements or refrained from concluding (new) agreements. In this category belong the recent terminations of certain of their BITs by Venezuela (e.g., with the Netherlands in 2008), ${ }^{3}$ South Africa (e.g., with Germany, Switzerland and the Netherlands in 2013), ${ }^{4}$ Ecuador (e.g., with Cuba, El Salvador, Guatemala, Honduras, Nicaragua, Paraguay, the Dominican Republic and Uruguay in 2008), ${ }^{5}$ or the announcement of Indonesia to terminate its investment treaties (e.g., with the Netherlands as of 2015). ${ }^{6}$ A variation has been the termination of the participation in the ICSID Convention or the negotiations of BITs without

3 See Luke Eric Peterson, 'Venezuela Surprises the Netherlands with Termination Notice for BIT; Treaty Has Been Used by Many Investors to "Route" Investments into Venezuela', IA Reporter, 16 May 2008 <www.iareporter.com/articles/20091001_93> (9 July 2014).

4 See 'SA Proceeds with Termination of Bilateral Investment Treaties', Creamer's Media's Engineering News, 21 October $2013<$ www.engineeringnews.co.za/article/sa-proceeds-with -termination-of-bilateral-investment-treaties-2013-10-21> (9 July 2014).

5 See 'Ecuador Terminates BITs with Eight LatAm States', Global Arbitration Review, 5 November $2008<$ globalarbitrationreview.com/news/article/14919/ecuador-terminates-bits-eight-latam -states/> (9 July 2014).

6 See 'Indonesia Terminates BIT' <www.minbuza.nl/en/key-topics/treaties/news/newsflashes -2014/indonesia-terminates-ibo.html $>$ (18 July 2014). 
investor-State dispute settlement. Venezuela denounced the ICSID Convention in 2012, Bolivia had done so already in 2007 and Ecuador in 2010. ${ }^{7}$ Australia and the United States have concluded a comprehensive free trade agreement (Australia-United States Free Trade Agreement - AUSFTA) in 2004 that included an investment chapter, but did not contain an investor-State dispute settlement mechanism. ${ }^{8}$ On the whole this approach remains however rather limited and is considered somewhat eccentric.

A second reaction (though much less noted) has been to simply continue negotiating BITs and to include the traditional standards together with an investor-State dispute settlement mechanism. Yet, this is rather rare as most new agreements include at least some modifications.

The third and maybe most common reaction has been to think about adapting the traditional rules of BITs. States try to continue to negotiate BITs or investment chapters in comprehensive trade and investment agreements by improving the language and taking into account the results of the general debate on the existing rules and the case law as developed by various arbitral tribunals. ${ }^{9}$ It is not always easy to demonstrate which provisions in new investment agreements are the results of such a reflection as, despite the similarity of many provisions in BITs, the exact working has always been subject to changes and modifications over time, sometimes even between concurrent agreements concluded by the same State with different partner countries.

This Special Issue of JWIT is about this third approach, i.e., to keep negotiating investment agreements and investment chapters (normally even including an investor-State dispute settlement mechanism) but to adapt the rules to the needs of the negotiating States in view of the known outcomes of investment disputes and the interpretation given therein to the traditional rules on investment protection. The articles in this Special were originally presented at a workshop organized in the framework of the LLM Program in International and European Economic and Commercial Law (Master of Advanced Studies) at the University of Lausanne (Switzerland) on 24 May 2012. All contributors work in the Greater Geneva area or Switzerland and focus on specific aspects

7 See the List of Contracting States and Other Signatories of the Convention available via $<$ icsid.worldbank.org/ICSID > (14 July 2014).

8 See Jürgen Kurtz, 'Australia's Rejection of Investor-State Arbitration' (2012) 27 ICSID ReviewFILJ 65-86 and the contributions in Michael Waibel et al. (eds.), The Backlash Against Investment Arbitration (Kluwer 2010).

9 See UNCTAD, Towards a New Generation of Investment Policies - World Investment Report 2012 (United Nations 2012) and UNCTAD, Investing in the SDGs: An Action Plan - World Investment Report 2014 (United Nations 2014). 
of international economic law in their work. It proved that the relevance of sustainable development for negotiating, adjudicating and interpreting BITs was a common theme that they all were able to contribute to. The notion of sustainable development can herein be seen as comprising a comprehensive set of public interests to be safeguarded by law. ${ }^{10}$

Anne Juliette Bonzon has undertaken a thorough study of the treaty practice of one of the States with most BITs in force, namely Switzerland. Switzerland is rather representative for the practice of a group of States to which also Germany, the Netherlands, Belgium or the United Kingdom belong. They have negotiated a large number of agreements in particular with developing countries after their independence and later also with communist countries during the Cold War, and then again with many transition countries and emerging economies in the 199os. Bonzon shows how Switzerland tries to balance traditional substantive and procedural rights granted to foreign investors with social and environmental provisions. Here the notion of sustainable development has impregnated many of the traditional provisions though it seems still rather uncertain whether the new language in some of Switzerland's agreements (as this practice is not yet fully uniform) will have an impact on the functioning of these agreements and their application by arbitral tribunals.

Anne van Aaken focuses in her contribution on what she calls "smart flexibility clauses" that aim at separating opportunistic behavior by host States (that should be sanctioned under international law) from bona fide public policy measures (that should not). She draws on economic contract theory as a basic framework, and political economy theory for fine-tuning.

Laurence Boisson de Chazournes and Brian McGarry emphasize the role domestic law, in particular constitutional law, can play to improve the outcome of arbitral decisions regarding investor-State disputes. They claim that a better outcome can be reached, for example, by deferring to domestic interpretations of constitutional principles, or to constitutional procedures that appear, for example, to protect fair and equitable treatment. An ignorance or blindness of arbitral tribunals for the concrete factual and legal situation in many States where foreign investment activities and the behavior by the authorities have led to disputes is often criticized (though not always demonstrated), and thus taking into account the domestic rule of law might lead to a

10 See Bruno Simma and Diane Desierto, 'Bridging the Public Interest Divide: Committee Assistance for Investor-Host State Compliance with the ICESCR' in D. Hanschel et al. (eds.), Mensch und Recht: Festschrift für Eibe Riedel zum 7o. Geburtstag (Duncker \& Humblot, 2013) 49-63 and Caroline Henckels, 'Balancing Investment Protection and the Public Interest' (2013) 4 Journal of International Dispute Settlement 197-215. 
more coherent outcome. This can be understood as taking into account in particular the social dimension of sustainable development by leading to enhanced interaction between the local or domestic level and the international sphere.

Faraz Rojid and Maria del Carmen Vasquez build on a presentation given by Elisabeth Tuerk at the Lausanne workshop on UNCTAD's Investment Policy Framework for Sustainable Development (IPFSD), which aims to assist policy makers in the design of a "new generation" of investment policies "that places inclusive growth and sustainable development at the heart of efforts to attract and benefit from foreign direct investment."11 After familiarizing the reader with the IPFSD and its relevance to poverty alleviation, they present three country-case-studies where foreign investors challenged regulatory measures aimed at alleviating poverty and discuss a series of IPFSD-based policy options that might help avoid such scenarios. As shown in their article, the UNCTAD framework can serve as a point of reference, offering a large number of policy options for negotiators to choose the "best-fit combination" for their particular country of investment protection and policy flexibility.

Krista Nadakavukaren Schefer focuses in her contribution on the economic dimension of sustainable development, i.e., the impact of the legal rules of the investment protection regime on poverty and on poverty's effects on investment law's goals. Poverty reduction is however at the interface of the economic and social dimension and thus clearly shows the sometimes contradictory needs of the poor (and thus most vulnerable) in developing countries. She tries to differentiate the different impact that property rights in the form of investment guarantees have in States that have already achieved a certain level of economic development and in least developed countries. She emphasizes also the role of NGOs (often through amicus curiae briefs) to influence arbitrators who, in their eyes, often are not active enough to interpret BITs in order to foster poverty reduction and use the agreements in the interest of the people directly affected by investment activities.

Tarcisio Gazzini, finally, assesses how States can take full advantage of investment treaties as vehicles for economic development without compromising on the protection of the environment, labour standard and human rights. He also provides a tentative taxonomy of the different treaty clauses and techniques that may contribute to create a stable and predictable legal framework for foreign investment that is also respectful of the various private

11 See Faraz Rojid and Maria del Carmen Vasquez, 'Investment Law and Poverty: Continuing the Debate through UNCTAD's Investment Policy Framework for Sustainable Development', in this issue, pp. 889-907. 
and public interests involved. He gives a broad overview of the techniques currently discussed and used to modify the traditional language of BITs without giving up the system and tested principles as such. He analyzes in particular the published model agreements by certain important players and the recent treaty practice of a wide variety of States. Here again, it becomes clear that many of the modifications are reactions to recent outcomes of specific arbitrations and are not always entirely tested as to what they mean for the overall coherence and balance of IIAs.

As one can see from all of these contributions the notion of sustainable development itself sometimes lacks the precision that might be useful to get proper guidance on how to reform existing BITs and negotiate better BITs in the future. ${ }^{12}$ At the same time, one can certainly no longer ignore it when negotiating IIAs and applying international investment law. Similarly to what has happened earlier in the area of trade, ${ }^{13}$ we now face a rebalancing of existing models in order to better integrate non-investment and investment policies. Changes related to sustainable development are, however, often mixed with modifications which have different rationales (such as the exact scope of the most-favored-nation clause or transparency provisions). On the whole, this certainly leads to more detailed agreements, which automatically makes them more complicated and increases the risk of inconsistencies within the text. Nevertheless, one must acknowledge that most of these modifications are immediate reactions to specific problems encountered in the past that hopefully can be solved through better provisions. We all know that new provisions will probably create new problems and lead to the discovery of more problems in other provisions that have not yet been challenged. The contributions in this volume are a modest attempt to contribute to the search for better BITs.

12 See Ulrich Beyerlin, 'The Concept of Sustainable Development' in R. Wolfrum (ed.), Enforcing Environmental Standards: Economic Mechanisms as Viable Means? (Springer 1996) 95-121 and Lorenzo Cotula and Kyla Tienhaara, 'Reconfiguring Investment Contracts to Promote Sustainable Development' in K. Sauvant (ed.), Yearbook on International Investment Law \& Policy 2011/12 (2013) 281-310.

13 See, e.g., United Nations/Environment Programme/Economics and Trade Unit, Introduction to Capacity Building for Environment, Trade and Sustainable Development (UNEP 2004), or, very early, Andreas R. Ziegler, Trade and Environment in the European Community (OUP 1996) and Julio García Burgués, 'Trade and Environment in the WTO' (1997) 6 Rev. European Community \& Int'l Envt'l L. 163-170. 